\title{
Big Enterprise Tax Risk Management: Warning, Simulation and Application*
}

\author{
De-fa Cai ${ }^{1}$, Nan-nan $\mathrm{Ni}^{1}$, and Jing $\mathrm{Cai}^{2}$ \\ 1. College of finance and public management, Harbin University of Commerce, \\ Harbin, P.R. China, 150028 \\ 2. Dalian Ocean University, Dalian, P.R. China, 116023 \\ abcd04754@126.com,2238166748@qq.com,caijing72@163.com
}

\begin{abstract}
Currently, the construction of "promoting tax compliance as the goal, the risk management as the guidance, taking the information tube tax and the hierarchical classification as the basis, set up tax services, risk monitoring, risk response to the new tax management system", this tax sources of specialized management model has become the direction of the reform of tax system, tax risk management as a new concept received extensive attention of tax authorities. Big enterprises are of the characteristics of small numbers, large scales, huge taxes and contributions, which is the core of tax collecting management. To strengthen the tax risk management ideas, and to direct taxpayers to perfect the inner tax control system are the important measures to implement individual services and pertinent management. This paper presents a flow chart of tax risk control and the four models: the identification model, the measurement model, the response model, the evaluation model, and simulation applications. Here, we take value-added tax as an example. In 2013, China's domestic value-added tax revenue is 2.8803 trillion yuan, accounting for $26 \%$ of the total income tax revenue, is one of China's current major taxes. Therefore, based on the data in the CTAIS to analyze the tax burden, and constructs the VAT tax burden warming system, is the effective measures to keep the rapid growth of VAT.
\end{abstract}

Keywords: tax risk; the identification model; the measurement model; the response model; the evaluation model; risk management; CTAIS;VAT

\section{Introduction}

Big enterprises, as to the tax collecting departments, are those of assets, incoming, and tax payment reached a certain level, and whose economic position can exert tremendous influence on the economic condition and fiscal ability of the nation or the area. At present, China's tax authorities to big enterprises involved in tax risk management deficiencies, mainly in the following aspects:

\subsection{Understanding of Tax Risk Management is Not Enough}

Mainly in two aspects: on the one hand, the individual risk of big enterprises lack of control mechanisms tax system, response to tax risk passively. Such as the big enterprises in Harbin City, the IRS office administration issued "the big enterprise tax risk

* Fund Project : Graduate research stage innovative research projects in Heilongjiang Province "Heilongjiang tax risk prevent and control research" (YJSCX2014-290HSD).

Author's profile : De-fa CAI (1966-), male, professor of finance, doctor of economics, mainly engaged in tax research. 
management guidelines (Trial)", after the big enterprise of the jurisdictions propagandizes the necessity and feasibility of tax risk management, but some individual companies, in a negative way to treat the tax risk, the most direct reasons for this state is the understanding of tax risk not enough. On the other hand, the tax authority also faced with the problem of insufficient. Compared with the traditional management, the big enterprises manage tax risk management model with front aspect, equality of both levied and the concept of service. As a novelty big corporate tax risk management model has not yet been approved for all tax officials to accept, levied equal legal status of both the concept has not been fully established, and some idea of tax officials are still hovering in hindsight management level, condescending and management perspective Later examination of traditional practices are hard to manage change in short time.

\subsection{Theoretical and Practical Support is Not Enough}

The tax risk identification and evaluation are the center links of the tax risk management, whose accuracy is directly related to the success or failure of tax risk management. At present, China is still no complete theory of tax risk management results, although in some countries of the world in this field has been relatively shaping experience, but because the different information sharing degree, the different tax management pattern, coupled with China's unbalanced economic development, makes risk identification, evaluation standards difficult to unity [1]. The State Administration of Taxation currently relying on the "three systems" to achieve the major aspects of risk management automation and intelligent, but still need tested its effectiveness through practice. A set of good tax risk management model is not just relying on software and hundreds of tax survey questionnaires can be achieved, it requires massive scientific theoretical basis for support, but also need by the accumulation of experience, and tax risk management model constantly optimize the sound to reach an ideal state.

\subsection{Policy Existence of Objective Complexity}

The complexity of the tax system and the elements correlation strong formed the risk, such as the general taxpayer qualification to manage complex, obligation for tax occurs, special provisions on multiple links and so on. Policy adjustments in a market economy result in risk, such as the tax rate adjustment, non gas, diesel oil tax tariff increase in the consumption tax, the tax policy change of waste materials industry and welfare enterprises. The policy change, the adjustment is too large to adapt or to understand and digest for the taxpayers, thereby causing risks. With the deepening of economic globalization, more and more companies began to "go out", in the process of enterprises "going out", to deal with complex and changeable international and domestic tax policy environment and strict tax collection and administration system, filled with a lot of tax risk [2].

\subsection{The Restricting of the Existing Conditions}

The existing conditions of the tax authorities cannot meet the needs of the existing big enterprises tax risk management. The first is the degree of information technology problems. Big enterprise tax risk management needs wide application of information technology, network technology, but now the tax authorities of tax information are still in the process of building and perfecting. The second is human resource issues. Tax risk management of big enterprises has just started, facing the problem of structural shortage of human resource challenges. Big enterprise tax management requirements in staffing based on expert-based, team-oriented working methods, the knowledge structure of an interdisciplinary team, cross-industry complex based. With the current status formed a strong contrast and difficult to solve within a short period of time. The third is the lack of 
understanding for big enterprises. The tax staff quality, management service force, tax collection and management conditions and other factors, so that the tax authorities is difficult for large enterprise production environment, financial accounting, and other aspects of the process to the extent not fully understand. The real terms of tax risk management is to manage big enterprise business background, such as cannot in-depth understanding of big enterprises, difficult to implement the tax risk management.

At present, the relevant research and practice of the tax risk identification in China is still in its infancy, has not yet established a fraud case database intelligent method for learning and training, the use of unsupervised learning methods are still found in high-risk individual taxpayers, including a variety of clustering algorithm, self- organizing feature map algorithm, principal component analysis and comprehensive evaluation methods, etc.; Tax risk identification analysis index system generally used to identify the elements listed, classified projects and so on. The method of measure tax risk assessment models in qualitative analysis is mainly expertise, and in quantitative analysis is mainly mathematical calculations and statistical evaluation [3].

\section{Tax Risk Prevention and Control Model Design}

Tax risk prevent and control includes the four steps: tax risk identification process, tax risk measurement process, tax risk response process and tax risk monitoring process, these four processes move in circles constantly update, and tax risk prevent and control in every link of the corresponding. Through the above process, the logical relationship of risk analysis identification, ranking, classification response, and performance evaluation is quite clear [4]. As shown in Figure 1:

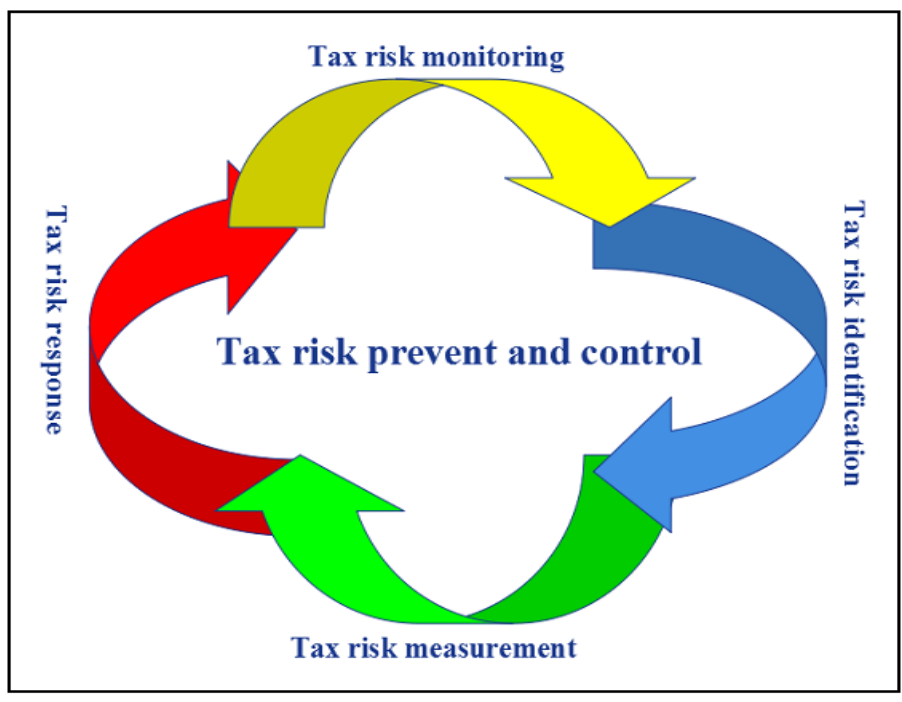

Figure 1. The Tax Risk Prevention and Control Flow Chart

\subsection{Tax Risk Identification Model}

Tax risk identification model is organic collection of tax risk index and the index weight, in the construction of the general tax risk identification model, first of all should grasp the macro factors and micro factors about tax risk. The macro factors generally include the economic situation, the laws and regulations, the tax policy and the administration mode. The micro factors include the taxpayer organization form, the industry characteristics, the process, the credit rating, the financial position and the operating results [5]. The process of tax risk identification is mainly on qualitative tax risk analysis process. Tax risk is influenced by economic factors, tax regulation, human habits 
and other factors, this process using Delphi Method, also called expert procedures of investigation. Use this method to develop the questionnaire, in accordance with established procedures, respectively to the members of the expert group for consulting by letters; Expert group members then anonymously (letter) to submit opinions. After several repeated consultation and feedback, the opinion of expert group members gradually tend to be concentrated, and finally achieved with high accuracy of the collective judgment result. Based on the fuzzy analytic hierarchy process (AHP), building the hierarchical model index system, the index system is divided into the One class index, the Two class index and the Three class index, and based on the key factors of tax risk to process and classify, prioritize, and then choose the more critical indicator [6]. The results are shown in Table 1.

Table . Tax Risk Index (Index Selection)

\begin{tabular}{|c|c|c|}
\hline One class index (score) & Two class index (score) & Three class index (score) \\
\hline \multirow{5}{*}{$\begin{array}{l}\text { Legal risk analysis } \\
\qquad\left(\mathrm{P}_{1 \mathrm{ij}}, \mathrm{S}_{1 \mathrm{ij}}\right)\end{array}$} & \multirow{2}{*}{$\begin{array}{c}\text { Constitutional risk }\left(P_{11 \mathrm{j}}, \mathrm{S}_{11 \mathrm{j}}\right. \\
)\end{array}$} & $\begin{array}{c}\text { Tax administrative litigation rate nearly } 3 \\
\text { years }\left(\mathrm{P}_{111}, \mathrm{~S}_{111}\right)\end{array}$ \\
\hline & & $\begin{array}{c}\text { Tax administrative reconsideration rate nearly } \\
3 \text { years }\left(\mathrm{P}_{112}, \mathrm{~S}_{112}\right)\end{array}$ \\
\hline & \multirow{3}{*}{$\begin{array}{l}\text { Institutional policy risk } \\
\left.\qquad \mathrm{P}_{12 \mathrm{j}}, \mathrm{S}_{12 \mathrm{j}}\right)\end{array}$} & Policy changes $\left(\mathrm{P}_{121}, \mathrm{~S}_{121}\right)$ \\
\hline & & Policy revision $\left(\mathrm{P}_{122}, \mathrm{~S}_{122}\right)$ \\
\hline & & Policy abolition $\left(\mathrm{P}_{123}, \mathrm{~S}_{123}\right)$ \\
\hline \multirow{4}{*}{$\begin{array}{l}\text { Political risk analysis } \\
\qquad\left(\mathrm{P}_{2 \mathrm{ij}}, \mathrm{S}_{2 \mathrm{ij}}\right)\end{array}$} & \multirow{2}{*}{$\begin{array}{l}\text { Domestic political risk }( \\
\left.\qquad \mathrm{P}_{21 \mathrm{j}}, \mathrm{S}_{21 \mathrm{j}}\right)\end{array}$} & $\begin{array}{c}\text { Important areas leadership change }\left(\mathrm{P}_{211}, \mathrm{~S}_{211}\right. \\
)\end{array}$ \\
\hline & & Election number per unit time $\left(\mathrm{P}_{212}, \mathrm{~S}_{212}\right)$ \\
\hline & \multirow{2}{*}{$\begin{array}{l}\text { International political risk } \\
\left.\qquad \mathrm{P}_{22 \mathrm{j}}, \mathrm{S}_{22 \mathrm{j}}\right)\end{array}$} & $\begin{array}{c}\text { Surrounding environment stability }\left(\mathrm{P}_{221}, \mathrm{~S}_{221}\right. \\
)\end{array}$ \\
\hline & & The main trade country's stability $\left(\mathrm{P}_{222}, \mathrm{~S}_{222}\right)$ \\
\hline \multirow{5}{*}{$\begin{array}{l}\text { Economic risk analysis } \\
\qquad\left(\mathrm{P}_{3 \mathrm{ij}}, \mathrm{S}_{3 \mathrm{ij}}\right)\end{array}$} & \multirow{3}{*}{$\begin{array}{l}\text { Domestic economic risk }( \\
\left.\qquad \mathrm{P}_{31 \mathrm{j}}, \mathrm{S}_{31 \mathrm{j}}\right)\end{array}$} & The GDP growth rate $\left(\mathrm{P}_{311}, \mathrm{~S}_{311}\right)$ \\
\hline & & The $\mathrm{M} 2$ growth rate $\left(\mathrm{P}_{312}, \mathrm{~S}_{312}\right)$ \\
\hline & & The CPI growth $\left(\mathrm{P}_{313}, \mathrm{~S}_{313}\right)$ \\
\hline & \multirow{2}{*}{$\begin{array}{c}\begin{array}{c}\text { International economic risk } \\
\left(\mathrm{P}_{32 \mathrm{j}}, \mathrm{S}_{32 \mathrm{j}}\right)\end{array} \\
\end{array}$} & International trade friction rate $\left(\mathrm{P}_{321}, \mathrm{~S}_{321}\right)$ \\
\hline & & Import and export growth rate $\left(\mathrm{P}_{322}, \mathrm{~S}_{322}\right)$ \\
\hline \multirow{4}{*}{$\begin{array}{l}\text { Cultural risk analysis } \\
\qquad\left(\mathrm{P}_{4 \mathrm{ij}}, \mathrm{S}_{4 \mathrm{ij}}\right)\end{array}$} & \multirow{2}{*}{$\begin{array}{l}\text { Traditional customs and } \\
\text { thoughts }\left(\mathrm{P}_{41 \mathrm{j}}, \mathrm{S}_{41 \mathrm{j}}\right)\end{array}$} & Risk Type Index $\left(\mathrm{P}_{411}, \mathrm{~S}_{411}\right)$ \\
\hline & & Approval degree $\left(\mathrm{P}_{412}, \mathrm{~S}_{412}\right)$ \\
\hline & \multirow{2}{*}{ Quality education $\left(\mathrm{P}_{42 \mathrm{j}}, \mathrm{S}_{42 \mathrm{j}}\right.$} & The average education years $\left(\mathrm{P}_{421}, \mathrm{~S}_{421}\right)$ \\
\hline & & $\begin{array}{l}\text { Compulsory education penetration rate ( } \\
\left.\qquad \mathrm{P}_{422}, \mathrm{~S}_{422}\right)\end{array}$ \\
\hline \multirow{6}{*}{$\begin{array}{l}\text { Compliance risk analysis } \\
\qquad\left(\mathrm{P}_{5 \mathrm{ij}}, \mathrm{S}_{5 \mathrm{ij}}\right)\end{array}$} & \multirow{3}{*}{$\begin{array}{l}\text { Tax compliance taxes } \\
\text { analysis }\left(\mathrm{P}_{51 \mathrm{j}}, \mathrm{S}_{51 \mathrm{j}}\right)\end{array}$} & The VAT $\left(\mathrm{P}_{511}, \mathrm{~S}_{511}\right)$ \\
\hline & & The consumption tax $\left(\mathrm{P}_{512}, \mathrm{~S}_{512}\right)$ \\
\hline & & Income tax $\left(\mathrm{P}_{513}, \mathrm{~S}_{513}\right)$ \\
\hline & \multirow{3}{*}{$\begin{array}{l}\text { Tax compliance Industry } \\
\text { analysis }\left(\mathrm{P}_{52 \mathrm{j}}, \mathrm{S}_{52 \mathrm{j}}\right)\end{array}$} & Processing and manufacturing $\left(\mathrm{P}_{521}, \mathrm{~S}_{521}\right)$ \\
\hline & & Modern service industry $\quad\left(\mathrm{P}_{522}, \mathrm{~S}_{522}\right)$ \\
\hline & & Common services $\left(\mathrm{P}_{523}, \mathrm{~S}_{523}\right)$ \\
\hline
\end{tabular}




\section{2 .Tax risk Measure Model}

The risk quantitative expression is:

$\mathrm{R}=\mathrm{P} \times \mathrm{S}$

" $R$ " is the degree of Risk, equal to the Risk accident frequency divided by the unit time; "P" is the Probability of risk, equal to the risk of accidents divided by the unit time; "S" is the Severity, equal to risk accidents divided by incidents.

Discrimination of the key index, such as: The tax burden rate $=$ (enterprise tax burden established industry tax)/established industry tax*100\%

Set the maximum value "a" and the minimum value "b", then the formation of an interval $(a, b)$,if the tax burden rate in the $(a, b)$,the enterprise tax management can be judged accurately, if the tax burden rate is higher than the maximum value "b", can be judged as the tax laws, the policies, or the regulations imperfect ;if the tax rate is lower than the minimum value "a", can be judged the enterprise tax compliance risk exist . When the absolute value of tax rate multiplied by the value of the enterprise scale, the greater the tax risk level will lead to greater individual indicators.

Single index is determined, is to explore the construction of general tax risk index, base on tax compliance risk as an example, its general expression is:

$\mathrm{ZR}=\Sigma \mathrm{R} \times \mathrm{w}$

"ZR" is tax compliance risk index score; " $\mathrm{R}$ " is single Risk index score; " $w$ " is the weight corresponding to individual indicator.

Sub-taxes, sub-scale, phased and other key indicators constructed by Criterion index system, find the tax risk identification point, and then calculate the enterprise total tax risk score by identifying points summary. Finally, integrating the total tax risk model:

$\mathrm{TR}=\Sigma \mathrm{Z}_{\mathrm{i}} \mathrm{R} \times \lambda$

"TR" is tax risk indicators total score; " $\mathrm{Z}_{\mathrm{i}} \mathrm{R}$ " is each subsystem risk score; " $\lambda$ " is the weight of each subsystem.

\subsection{Tax Risk Response Model}

Through the tax risk identification model and measurement model to quantify the tax risk, and the tax risk classification becomes very easy. According to the predetermined standards, combined with the regional policy regulation target, and classify the value of tax risk management at different levels, need to establish the tax risk early warning model. The tax risk early warning and prevention should adhere to the principle of right to distinguish the two types of tax risks, the exogenous and the endogenous, comprehensive analysis, focusing on monitoring. The exogenous tax risk prevention and resolution, can only rely on reform and optimization of the political, economic, cultural, and legal system, thereby eliminating the risk points, defuse risks. And prevent and resolve endogenous tax risk, because the tax is subject to exogenous risk factors, can prevent and resolve in a limited range [7]. Follow above principle, build the tax risk early warning "radar" model, through the risk graph method, also known as the risk matrix method, for the whole project's overall risk early warning, can also be a subsystem of the project. For example, only a simple project subsystem simulation. General risk quantification expression is: $\mathrm{R}=\mathrm{P} \times \mathrm{S}$

Classified according to the tolerance range of preset tax risk, with the information technology platform as the carrier, the collection and management of information system and inspection tour of various types of information collected was analyzed, to identify the risks. The tax risk set into five grades, according to the tax risk level to implement management measures, implementation of daily tax services and encourage risk enterprises to normal level, the implementation of the policy guidance to the risk enterprises have a certain degree of risk, tax assessment implementation risk enterprises to high risk grade, direct the implementation of the tax inspection the risk of enterprise of high risk grade [8]. If the tolerance interval is set to: Risk score above 80 is set to high 
risk degree, risk score at $[54,80)$ is set to the second level high risk degree, at $[40,54)$ is set to the third level high risk degree, at $[12,40)]$ is set to there is some risk, risk score below 12 is set to normal. As shown in Figure 2-3:

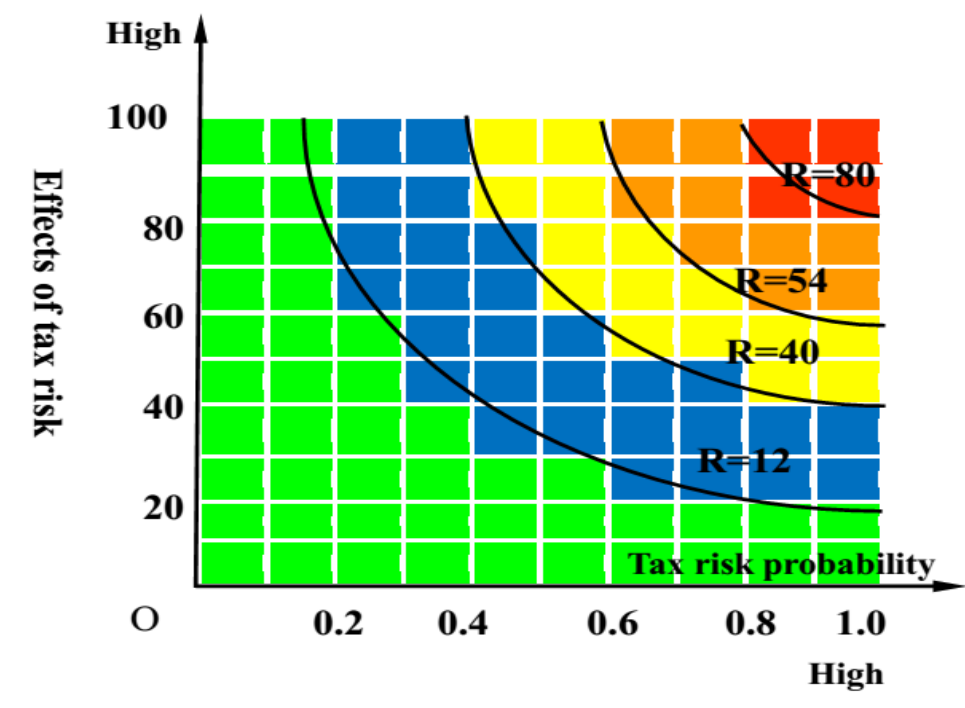

Figure 2. The Tax "Radar" Early Warning Module

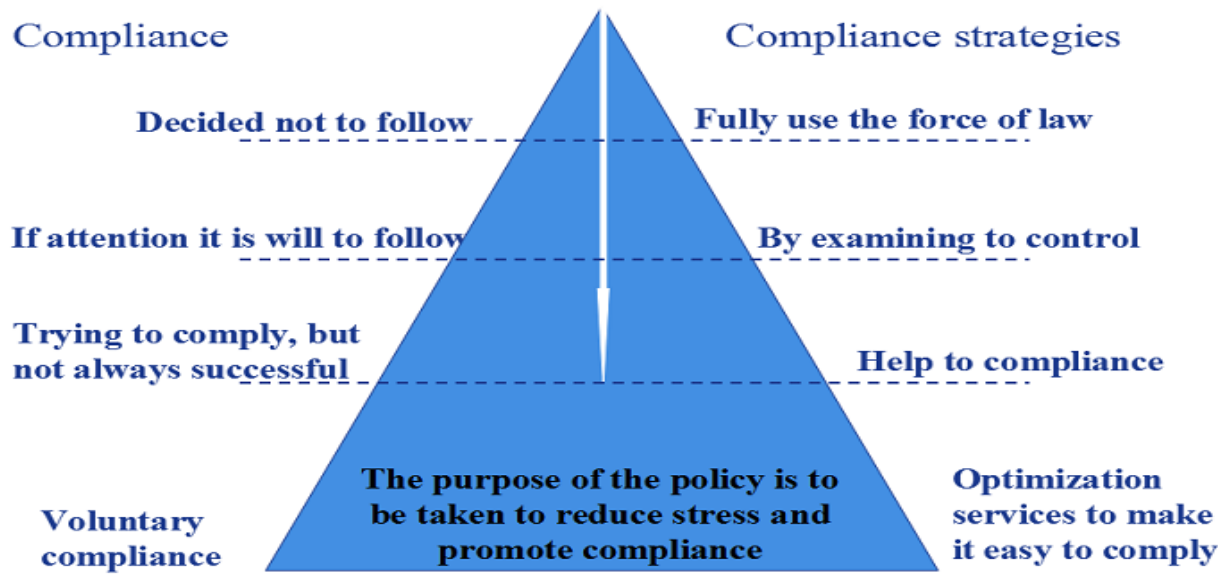

Figure 3. The Tax Risk Response Processing Model

\subsection{Tax Risk Evaluation Model}

This model is in the course of tax risk prevention and control making policy, the effect of the implementation of the policy implementation, the implementation of the program control, to ensure proper policies, shall timely implementation. However, decentralized control tax risk meanwhile, not one-sided pursuit of tax risk is minimized, because the cost of the tax would increase, as shown in Figure 4: 


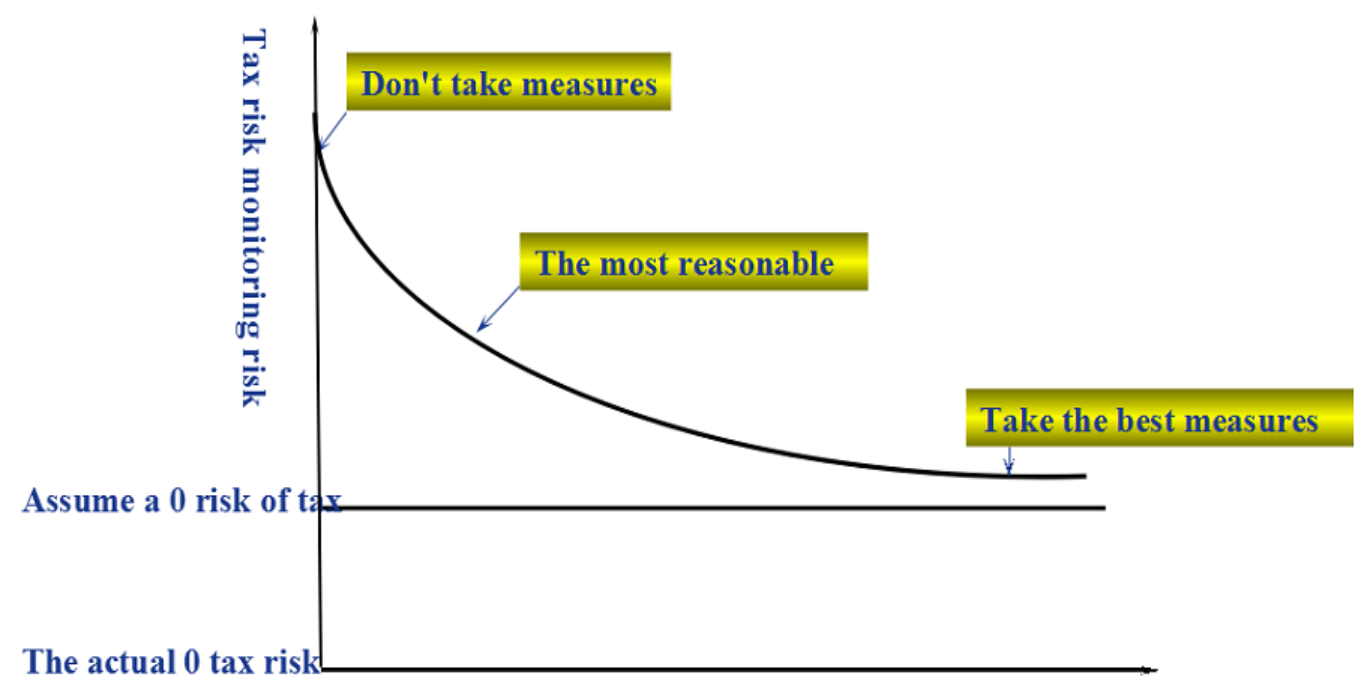

Tax risk monitoring cost

Figure 4. Tax Risk Monitoring Costs

As can be seen from Figure 4, when not to take any risk prevention and control measures, the tax risk is very high, but the tax risk monitoring cost is 0 ; when to take the most advanced technical means to control the tax risk, making the tax risk tends to 0,the corresponding tax risk monitoring costs also increased accordingly ;only by the output method to find out the best tax risk monitoring cost point, making tax risk within tolerable to accept a relatively low range, and the smallest cost of tax risk monitoring is the best point.

\section{Simulation of the Tax Risk Control Model}

Assume that a province by the expert scoring evaluation, the total score is 100 points, three-level index score is shown in Table 2:

Table . Tax Risk Index System (Index Score)

\begin{tabular}{|c|c|c|}
\hline One class index (score) & Two class index (score) & Three class index (score) \\
\hline \multirow{5}{*}{$\begin{array}{l}\text { Legal risk analysis } \\
\quad(0.01,39.95)\end{array}$} & \multirow{2}{*}{ Constitutional risk $(0.4,50)$} & $\begin{array}{l}\text { Tax administrative litigation rate nearly } \\
3 \text { years }(0.3,50)\end{array}$ \\
\hline & & $\begin{array}{l}\text { Tax administrative reconsideration rate } \\
\text { nearly } 3 \text { years }(0.7,50)\end{array}$ \\
\hline & \multirow{3}{*}{$\begin{array}{l}\text { Institutional policy risk ( } \\
0.6,33.25)\end{array}$} & Policy changes $(0.35,30)$ \\
\hline & & Policy revision $(0.35,35)$ \\
\hline & & Policy abolition $(0.3,35)$ \\
\hline \multirow{4}{*}{$\begin{array}{l}\text { Political risk analysis } \\
\quad(0.005,52.8)\end{array}$} & \multirow{2}{*}{ Domestic political risk $(0.6,56$} & $\begin{array}{l}\text { Important areas leadership change }( \\
0.8,60)\end{array}$ \\
\hline & & Election number per unit time $(0.2,40$ \\
\hline & \multirow{2}{*}{$\begin{array}{l}\text { International political risk } \\
0.4,48)\end{array}$} & $\begin{array}{l}\text { Surrounding environment stability ( } \\
0.6,40)\end{array}$ \\
\hline & & $\begin{array}{l}\text { The main trade country's stability } \\
0.4,60)\end{array}$ \\
\hline Economic risk analysis & Domestic economic risk & The GDP growth rate $(0.3,35)$ \\
\hline
\end{tabular}




\begin{tabular}{|c|c|c|}
\hline \multirow[t]{4}{*}{$(0.2,36.4)$} & \multirow[t]{2}{*}{$0.8,33)$} & The M2 growth rate $(0.3,35)$ \\
\hline & & The CPI growth $(0.4,30)$ \\
\hline & \multirow{2}{*}{$\begin{array}{l}\text { International economic risk } \\
0.2,50)\end{array}$} & $\begin{array}{l}\text { International trade friction rate }(0.4,50 \\
\text { ) }\end{array}$ \\
\hline & & $\begin{array}{l}\text { Import and export growth rate }(0.6,50 \\
\text { ) }\end{array}$ \\
\hline \multirow{4}{*}{$\begin{array}{l}\text { Cultural risk analysis } \\
\qquad(0.3,50)\end{array}$} & \multirow{2}{*}{$\begin{array}{l}\text { Traditional customs and } \\
\text { thoughts }(0.4,50)\end{array}$} & Risk Type Index $(0.3,50)$ \\
\hline & & Approval degree $(0.7,50)$ \\
\hline & \multirow[b]{2}{*}{ Quality education (0.6,50) } & The average education years $(0.5,40)$ \\
\hline & & \begin{tabular}{|l} 
Compulsory education penetration rate \\
$(0.5,60)$
\end{tabular} \\
\hline \multirow{6}{*}{$\begin{array}{l}\text { Compliance risk analysis } \\
\qquad(0.4,34)\end{array}$} & \multirow{3}{*}{$\begin{array}{l}\text { Tax compliance taxes analysis } \\
(0.5,34)\end{array}$} & The VAT $(0.3,35)$ \\
\hline & & The consumption tax $(0.2,30)$ \\
\hline & & Income tax $(0.5,35)$ \\
\hline & \multirow{3}{*}{$\begin{array}{l}\text { Tax compliance Industry } \\
\text { analysis }(0.5,34)\end{array}$} & $\begin{array}{l}\text { Processing and manufacturing }(0.3,35 \\
\end{array}$ \\
\hline & & Modern service industry $(0.5,35)$ \\
\hline & & Common services $(0.2,30)$ \\
\hline
\end{tabular}

Under the conditions of the province's legal risks and constitutional risks, the probability of three class index tax administrative litigation nearly three years is 0.3 , and the impact of tax constitutionalism score is 50; the probability of taxation administrative reconsideration occurred in recent 3 years is 0.7 (Only the tax administrative litigation and the tax administrative reconsideration affect constitutional risk, ignore regardless of other conditions), the impact of tax constitutionalism score is 50 .

The probability of two class index constitutional risk fuzzy evaluation by experts occurrence is 0.4 ,The contribution of two class index "Constitutional risk" to one class index "Legal risk" score is equal to $(0.3 * 50+0.7 * 50)=50$

Similarly, the probability of two class index evaluation system policy risks can be obtained by occurring is 0.6 (Assuming only the constitutional risk and policy risk affect the legal risk), "Institutional policy risk" contribution to One class index "Legal risk" score is equal to $(0.35 * 30+0.35 * 35+0.3 * 35)=33.25$

The probability of one class index legal risk fuzzy evaluation by experts occurrence is 0.01 , and the score is equal to $(0.4 * 50+0.6 * 33.25)=39.95$, the Tax Legal Risk $=0.01 * 39.95=0.3995$

With the same method, the Tax Legal Risk score is 0.3995, the Tax Political Risk score is 0.264, the Tax Economic Risk score is 7.28, the Tax Cultural Risk score is 15, the Tax Compliance Risk score is 13.6.

And the Comprehensive Tax Risk is equal to $(0.01 * 39.95)+(0.005 * 52.8)+(0.2 * 36.4)$ $+(0.3 * 50)+(0.4 * 34)=0.3995+0.264+7.28+15+13.6=36.5435$

Set by a tolerable range score, the province's tax risk score falls in $[12,40)$, belongs to there is some risk, reflects in the tax risk early warning "radar" map, in the blue area, reflects in the risk response processing model, response measures should be taken to help its compliance. However, the province's score 36.5435 is close to $\mathrm{R}=40$, and between the line of blue and yellow, should pay more attention to its development trend in real time, once the risk score increase, appropriate control measures should be taken immediately. 


\section{The VAT Tax Burden Warning Model and M based on CTAIS System Date}

VAT tax warning system adopts n-tier structure design, adopt data focused way, all data and programs are stored in the backend server bureau information center, the bureau information center unified maintenance, front desk only user application interface, various departments to actual operation according to the business needs. "Golden Tax Phase III" project is based on tax data "big focus" as the core, for future tax service provides a highly modernized, information platform, to ensure the authenticity and reliability of the data [9].

\subsection{System Structure}

The structure of this system is mainly dependent on the database server ORACLE, ORACLE has a good performance in database management function, integrity checking, security, consistency, by permission to control users to access the database, database audit and trace, to monitor the database usage, the processing of data into the database serverside and client-side applications, shared data from the centralized database management systems, database applications and software running in client [10]. First, the provincial bureau CTAIS data put into the bureau database server ORACLE, and then by the data processing components of its tax data processing, classification, operation treatment, the results of storage in the background ORACLE data tables since definition, through application logic will display the information users need. As shown in Figure 5 shows:

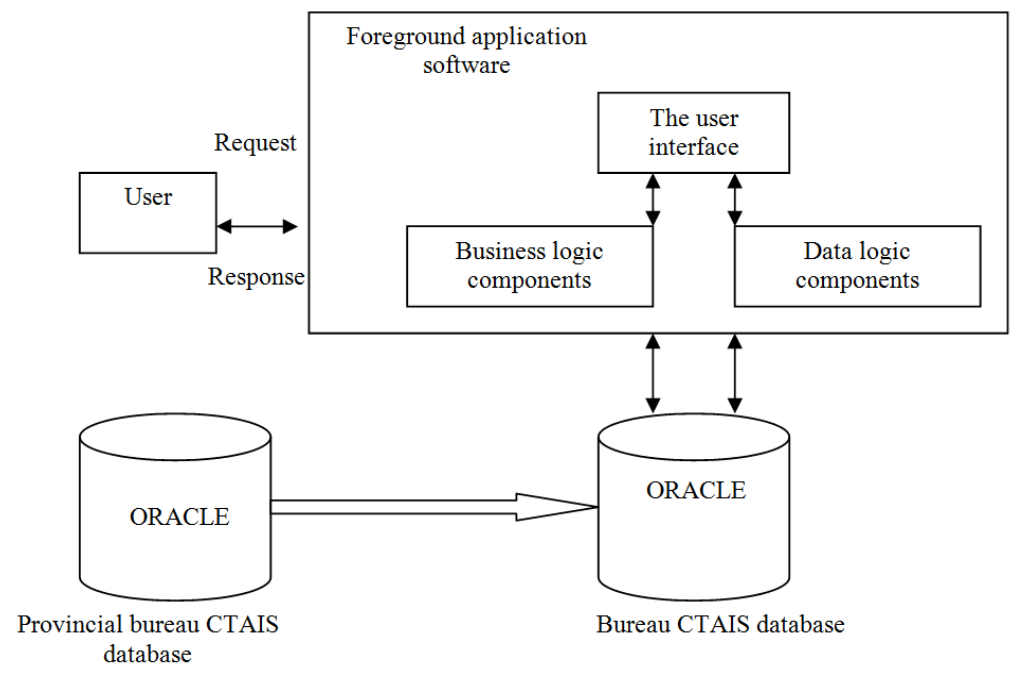

Figure 5. System Structure

\subsection{Function Design}

To achieve full system tax warning analysis, construction work intelligent tax warning system should have the main features include: (1) Tax diagrams, contrast curve and industry tax burden distribution. (2)All enterprises' conditions in the city of industries that their tax burden is lower than the early warning value, the early warning value of a certain industry and the whole system District (County) bureau of early warning value below statistics and statistical figure. (3) By the District (County) bureau show the warning situation. (4) Discrete coefficient setting. (5)Input the Administration and the Provincial Bureau of the industry average tax burden.(6) The industry average tax burden contrast 
curve of the Administration, the Provincial Bureau and the Bureau. (7) Tax burden analysis and calculation function.

\subsection{Constructing Model}

4.3.1. Basic Model: Main basic indicators are mean value, distribution, discrete degrees, period and trend, associated with the actual tax situation of each city tax to achieve early warning. Tax burden early warning mainly refers to the trade tax burden early warning, the research of trade tax burden is relatively about the same industry relationship between the individual and the whole as well as individual and individual tax burden, the trade tax analysis is to find out the characteristics of all kinds of tax burden between the same industry has, and summarize the characteristics to provide data to support the practice of tax collection and administration [11].

a. Objective level estimates on tax revenue of all enterprises in cities. The objective level in tax revenue analysis is the mean value in mathematical analysis, using the formula of calculating mean value in which xi represents the actual tax burden of each enterprises in the industry while $\mathrm{n}$ is the number of enterprises.

b. Measure of the sample distribution range. Analysis object samples of specific indicators foothold distribution can use standard deviation to describe, therefore, sample distribution range of estimates, to a certain extent, to measure the standard deviation, measuring the standard definition with reasonable interval object scope for control of measuring objects, provide a reference basis for running trajectory. It is through the analysis for the tax burden for industry to find the industry standard and the scope of the tax burden reasonable interval. In the standard deviation formulas the $\mathrm{s}$ for the standard deviation of tax burden, xi for the industry average actual tax burden, $\bar{x}$ for the industry average tax burden, $\mathrm{n}$ for enterprise quantity.

c. Determine the tax burden warning limits. To define a reasonable interval of standard deviation is a general concept, The actual work for specific object, standard deviation is scattered sample distribution, to define objects too scope of excessive, can than the objective environment or condition requirements. Therefore, when in setting warning interval, sample discrete relative concept, namely the formula is discrete coefficients of discrete systems mentioned above the formula. For tax analysis, the $\delta$ which the discrete coefficient of tax burden of a industry is the discrete coefficient using the formula obtained above, in which s for the industry's standard deviation of tax burden, $\bar{x}$ for the average tax burden of a industry. Some industry of discrete coefficients is the duty of the industry standard of the industry average tax with a relative size of the tax burden relationship. Reference the relationship of scale size, to define the warming limits of the analysis object. Combined with the actual tax situation, can reference 100 points for 60 points for practice to determine failed reference, the idea of dividing the warning line is by $\delta \leq 0.6$,enterprise tax burden of reasonable value range for $\bar{x}_{-\mathrm{s}} ; \delta>0.6$, the enterprises reasonable scope for the tax burden for ${ }^{\bar{x}}-0.6^{\bar{x}}$.

d. Extraction taxpayers list beyond the warning line. With the value of the warning line, using this value with the industry the tax burden on all taxpayers to compare the situation, any lower than this value will be taken out of them.

4.3.2. Clustering Analysis Model: Clustering analysis refers to analysis the set composed of a plurality of abstract objects and physical objects, or the analysis of different types composed of similar objects. In the view of statistics, the clustering analysis as a method to simplify the data and modeling; and if from the application point of view, it can be a tool for clustering as an access to the data distribution, observe the characteristics of different data clusters, and analysis the specific collection. ${ }^{[12]}$ Because there is an inevitable connection between value-added tax burden and value-added tax 
rate, the two should keep pace with change. Therefore, it can with a fair tax for clustering principle, in average tax rate and the average tax burden for clustering core to develop cluster analysis.

a. The first clustering analysis: with the value of the average value-added rate and the average tax burden ratio of the boundaries coefficient, all enterprises industry are divided into two parts, greater than the coefficient of the regional feature is high value-added tax rate, low tax burden, in this region of domain each sample points that the vertical distance from the boundary is faraway, the performance of "low tax burden". Below this coefficient the characteristics of the area is low value-added and high tax burden, in this region of domain each sample points the vertical distance from the boundary is close, the performance of "high tax burden." First clustering conclusion is too thick, not easy to operate to realize, that requires further clustering.

b. The second clustering analysis: with the average value-added rate and the average tax burden rate for the sample focus, the sample is divided into four categories: high value-added high tax burden area, high value-added low tax burden area, low value-added high tax burden area, low value-added low tax burden area. Through the second clustering analysis more easily to grab the key enterprises, namely high value-added low tax burden. In order to find the enterprise which have a problem, need further clustering analysis.

c. The third clustering analysis: with the average value-added rate and the average tax burden rate for the sample center, estimate the distance from the center of the sample. The greater the distance, the high requirements of feature separating from sample the performance, should be separated, classify as "alternative". These "alternative" enterprise is to concentrate on the list. Therefore, from high value-added low tax burden area can find "alternative" enterprise.

Adopting clustering analysis needs to use the enterprise value-added rate, enterprise value-added rate is the ratio that the enterprise added value with the enterprise main business income. Because in actual work cannot be obtained the enterprise added value the fundamental parameters from CTAIS, it cannot use cluster analysis to undertake handling.

4.3.3. Model Comparison: Clustering analysis is further analysis that based on the basic model, which have relative complexity of the operation rules, large amount of computation, but its advantage is obvious, which is able to more accurately locate the problem enterprise. Basic model is not analyzed detailed enough, screening out the proportion of enterprises is to large, according to current experience, about more than $40 \%$, not easy to handle, thus can adopt the method of combining both, namely, based on the analysis of basis model according to actual experience value to do a simple clustering, find out the lower tax burden enterprise. This will not only realize this method from the practical work, but also achieve expected targets.

4.3.4. System Optimization: The computation in above model is huge, and in the tax analysis work will continue to view the warning situation, it is unrealistic that every time view the warning tax burden situation on the industry are calculated, so optimize it.

First, because it is amazing the tax burden calculation, algorithm should realize in the database server, namely ORACLE use the stored procedure to realize the algorithm of tax burden analysis, in order to prevent large amounts of data transmitted in the network, also reduce data traffic, achieve the purpose of improving program execution efficiency.

Second, focus on a regularly analysis and calculation on the full industry about tax burden, and store the computing results and final results in the background database, for future tax burden operations are shifted to query the already calculated results.

Third, due to dispersion coefficient is set based on experience value, with the deepening of value-added tax analysis work, will likely change, so discrete coefficients 
should be kept in the database, allows users to modify, in order to improve the flexibility of the system.

\section{The Basic Conclusions}

VAT tax warning system reduced tax administrator burden, improve work efficiency, for all levels of leaders to provide accurate detailed information, such as realized the automatic low tax payers and low tax burden situation statistics, the screening low taxes burden payer ,the comparison among low tax burden payers between vertical and horizontal, the search abnormal households, realize the intelligent search of value-added tax analysis work, facilitate to a targeted tax burden investigation, realize the comparison among the taxpayer in the system and industry tax burden, the historical data of low tax burden taxpayers and extracted automatically low tax payers, to achieve the desirable design effects.

\section{References}

[1] G.-j. Zhu and L.-h. Zhang, "Taxation Institute of State Administration of Taxation Science Research Group", Research in Application of Risk Management Theory in Tax Collection and Administration, J. Tax economic research, vol. 1, (2014), pp. 26-32.

[2] B. Chen, "Tax Risk Management of "Going out" Enterprises", J. Communication of finance and accounting, vol. 17, (2010), pp. 152-153.

[3] B.-y. Lei, "The Practice of Tax Risk Management to Promote the Tax Source Management Scientific", J. China tax, vol. 2, (2009), pp. 53-54.

[4] D.-m. Xu, J.-x. Zou, J.-d. Deng and Q.-h. Zhang, Jiangsu Province Wuxi City State Taxation Bureau "Risk Management" Research Group, The Preliminary Practice and Optimization of Thinking on Tax Risk Management, J. Tax research, vol. 4, (2010), pp. 89-91.

[5] J.-h. Zhang, "Construction of the Tax Risk Identification Model, J. Taxation and economy, vol. 1, (2014), pp. 96-99.

[6] Z.-m. Lv, "Tax Risk Assessment Based on Fuzzy Analytic Hierarchy Process", J. Statistics and decision, vol. 13, (2011), pp. 161-163.

[7] X.-g. Yao and C.-t. Wei, "Early Warning and Prevention of Tax Risk", J. China economic report, vol. 1, (2014), pp. 57-62.

[8] Q.-y. Qi, "Explore “4 +2" Work Act, Out New Ways to Strengthen the Tax Administration”, J. Chinese tax, vol. 5, (2010), pp. 41-42.

[9] C.-h. Luan, C. Liu and Z. Hou, "Tax Risk Management under the Framework of the "Golden Tax Phase III" Project", J. Chinese tax, vol. 6, (2010), pp. 52-53.

[10] L. Han, "Oracle Database Optimization Design”, J. Youth, vol. 7, (2013), p. 447.

[11] X.-1. Wu and R.-j. Jiao, "Interbank Tax Theory and Its Application in Tax Administration Work", J. Tax research, vol. 11, (2003), pp. 21-23.

[12] J. Zhang, "MS-based Data Clustering Model Mining Research", J. Chinese investment in technology, vol. Z1, (2013) , p. 41. 